\section{Jeotgalibacillus alimentarius gen. nov., sp. nov., a novel bacterium isolated from jeotgal with L-lysine in the cell wall, and reclassification of Bacillus marinus Rüger 1983 as Marinibacillus marinus gen. nov., comb. nov.}

\author{
Jung-Hoon Yoon, ${ }^{1}$ Norbert Weiss, ${ }^{4}$ Keun-Chul Lee, ${ }^{1}$ In-Sun Lee, ${ }^{2}$ \\ Kook Hee Kang ${ }^{3}$ and Yong-Ha Park ${ }^{1,2}$
}

\footnotetext{
Korea Research Institute of Bioscience and Biotechnology (KRIBB), PO Box 115, Yusong, Taejon, Korea

2 Probionic Corporation, Bio-venture Centre, Korea Research Institute of Bioscience and Biotechnology (KRIBB), PO Box 115, Yusong, Taejon, Korea

3 Department of Food and Life Science, Sungkyunkwan University, Chunchun-dong 300 , Jangan-gu, Suwon, Korea

${ }^{4}$ DSMZ - Deutsche Sammlung von Mikroorganismen und Zellkulturen $\mathrm{GmbH}$, Mascheroder Weg 1b, D-38124 Braunschweig Germany
}

\begin{abstract}
Author for correspondence: Yong-Ha Park. Tel: +82 42860 4620. Fax: +82 428621315 e-mail: yhpark@mail.kribb.re.kr
\end{abstract}

\begin{abstract}
A moderately halophilic, round-endospore-forming bacterium (strain $\mathrm{YKJ}^{\mathrm{K}}-13^{\mathrm{T}}$ ) was isolated from jeotgal, a traditional Korean fermented seafood, and studied by a polyphasic taxonomic approach. This organism was related to the phylogenetic clade comprising members of Bacillus rRNA group 2 and formed a cluster with Bacillus marinus with a bootstrap fidelity value of $93.6 \%$. The peptidoglycan type was A1 $\alpha$ linked directly through L-Lys. Based on cell

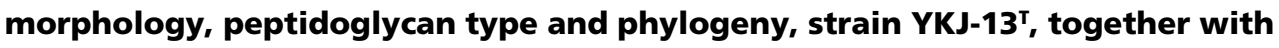
B. marinus, is considered to be a member of Bacillus rRNA group 2. Strain YKJ$13^{\top}$ was also characterized by having MK-7 and MK-8 as the predominant menaquinones and iso- $C_{15: 0}$ as the major fatty acid. The DNA G+C content was 44 mol\%. Strain YKJ-13' ${ }^{\top}$ exhibited a 16 S rDNA similarity value of $95 \cdot 7 \%$ with $B$. marinus DSM 1297', its closest phylogenetic relative. Levels of $16 \mathrm{~S}$ rDNA similarity between strain $\mathrm{YKJ}^{-13^{\top}}$ and other Bacillus spp. were less than $\mathbf{9 4 \cdot 2} \%$. Therefore, on the basis of the data presented, the name Jeotgalibacillus alimentarius gen. nov., sp. nov. is proposed for strain YKJ-13' ( = KCCM $80002^{\top}$ $=J C M 10872^{\top}$ ). It is also proposed that $B$. marinus be reclassified in Marinibacillus gen. nov. as Marinibacillus marinus comb. nov.
\end{abstract}

Keywords: Jeotgalibacillus alimentarius, Bacillus marinus, Marinibacillus marinus, Bacillus rRNA group 2, jeotgal

\section{INTRODUCTION}

Jeotgal, one of the representative traditional foods of Korea, is prepared through blending of various kinds of seafoods, including seawater and other ingredients, and becomes palatable through proper preservation. Preliminary studies on the microbiology of jeotgal have demonstrated the presence of a variety of bacterial strains; the majority of the isolates were Gram-positive or -variable, endospore-forming bacilli. Considering their halotolerant or halophilic physiological properties, most of bacterial isolates appear to have originated from seafoods and seawater. Among many bacilli from jeotgal, a round-endospore-forming,

The GenBank accession number for the 165 rDNA sequence of strain YKJ-13 ${ }^{\top}$ is AF281158. moderately halophilic bacterium (strain $\mathrm{YKJ}-13^{\mathrm{T}}$ ) was studied in this report.

Formation of round endospores is a typical characteristic of organisms assigned to Bacillus rRNA group 2 , which are characterized by having L-lysine or Dornithine at position 3 of the peptide subunit of the peptidoglycan (Rheims et al., 1999; Stackebrandt et al., 1987). Bacillus species belonging to this group form the radiation of a cluster distinct from members of other rRNA groups of the genus Bacillus (Ash et al., 1991; Stackebrandt et al., 1987). However, it should be noted that this group also consists of a phylogenetic jumble with some non-Bacillus-type organisms, such as the genera Caryophanon, Planococcus, Filibacter and Sporosarcina (Clausen et al., 1985; Farrow et al., 1992, 1994; Stackebrandt et al., 1987). On the basis of these properties, it has been recognized that the L- 
lysine- and D-ornithine-containing bacilli belonging to rRNA group 2 may have to be taxonomically reevaluated (Farrow et al., 1994; Rheims et al., 1999).

In the present work, the morphological, phenotypic and phylogenetic characteristics of strain $\mathrm{YKJ}-13^{\mathrm{T}}$ are described in order to unravel its exact taxonomic status. This organism has taxonomic properties indicative of rRNA group 2 bacilli. Results of 16S rDNA sequence comparison showed that strain $\mathrm{YKJ}-13^{\mathrm{T}}$ is phylogenetically most closely related to Bacillus marinus, with formation of a coherent cluster. $B$. marinus was later elevated to species rank by Rüger (1983) with strains that had originally been described as Bacillus globisporus subsp. marinus by Rüger \& Richter (1979). This species has been known to produce round-spore-forming cells and contain lysine in the cell wall (Rüger, 1983; Claus \& Berkeley, 1986). Nevertheless, B. marinus had rarely been included within Bacillus rRNA group 2 because of the lack of chemotaxonomic data, e.g. the cell wall murein type and menaquinone type (Ash et al., 1991; Rheims et al., 1999). Moreover, the 16S rDNA sequence of $B$. marinus, which would have been an important criterion for grouping this species within rRNA group 2, was not available until a recent publication by Rüger et al. (2000). In the study of Rüger et al. (2000), it was also shown that the type strain of B. marinus has a cell wall peptidoglycan type linked directly through L-lysine. The objective of the present study was to determine the exact taxonomic status of $B$. marinus as well as that of strain $\mathrm{YKJ}-13^{\mathrm{T}}$. On the basis of results presented, it is proposed that strain $\mathrm{YKJ}-13^{\mathrm{T}}$ should be classified as Jeotgalibacillus alimentarius gen. nov., sp. nov., and $B$. marinus should be reclassified in Marinibacillus gen. nov. as Marinibacillus marinus comb. nov.

\section{METHODS}

Bacterial strains and culture conditions. Strain YKJ-13 $3^{\mathrm{T}}$ was isolated from jeotgal, a traditional Korean fermented seafood, by a dilution plating technique on marine agar (Difco). B. marinus DSM $1297^{\mathrm{T}}$, used as a reference strain, was obtained from Deutsche Sammlung von Mikroorganismen und Zellkulturen (DSMZ), Braunschweig, Germany. Cell mass for analyses of the cell wall and menaquinones and for DNA extraction was obtained from marine broth (Difco) culture grown at $30^{\circ} \mathrm{C}$ for strain YKJ$13^{\mathrm{T}}$ or $20^{\circ} \mathrm{C}$ for B. marinus DSM $1297^{\mathrm{T}}$. Strains were cultivated on a horizontal shaker at 150 r.p.m. and the broth cultures were checked for purity microscopically before being harvested by centrifugation. For fatty acid methyl ester analysis, cell mass of strain $\mathrm{YKJ}-13^{\mathrm{T}}$ and $B$. marinus DSM $1297^{\mathrm{T}}$ was obtained after growth for $3 \mathrm{~d}$ at $30^{\circ} \mathrm{C}$ on marine agar.

Morphological characterization. The morphologies of colonies and cells grown on marine agar were examined. Cell micromorphology was observed using phase-contrast microscopy and transmission electron microscopy. Flagellum type was determined using transmission electron microscopy with cells from an exponentially growing culture. For transmission electron microscopic observation, cells were negatively stained with $1 \%(\mathrm{w} / \mathrm{v})$ phosphotungstic acid and, after air-drying, the grids were examined with a model CM20 transmission electron microscope (Philips).

Physiological characterization. All physiological tests were performed at $30^{\circ} \mathrm{C}$, except for the study of temperature range for growth. Oxidase activity was determined by examining oxidation of $1 \% p$-aminodimethylaniline oxalate. Catalase activity was determined by bubble formation in a $3 \%(\mathrm{v} / \mathrm{v})$ hydrogen peroxide solution. Hydrolysis of aesculin and nitrate reduction were determined as described previously (Lanyi, 1987). Hydrolyses of casein, gelatin, starch and Tween 80, and urease activity were determined as described by Cowan \& Steel (1965). Hydrolyses of hypoxanthine, tyrosine and xanthine were performed on marine agar with concentration of substrates described previously (Cowan \& Steel, 1965). Acid production from carbohydrates was determined as described by Leifson (1963). Growth under anaerobic conditions was determined after incubation in an anaerobic chamber with marine agar that was anaerobically prepared. Growth at various $\mathrm{NaCl}$ concentrations was investigated on marine agar or in marine broth. Growth at various temperatures was measured on marine agar or in marine broth at $4-55^{\circ} \mathrm{C}$.

Isolation of DNA. Chromosomal DNA was isolated and purified according to a previously described method (Yoon et al., 1996), with the exception that ribonuclease T1 was used together with ribonuclease A.

Chemotaxonomic characterization. Preparation of the cell wall and determination of peptidoglycan structure were carried out by the methods described by Schleifer \& Kandler (1972) with the modification that TLC on cellulose sheets was used instead of paper chromatography. Menaquinones were analysed as described previously (Komagata \& Suzuki, 1987) using reversed-phase HPLC. For quantitative analysis of cellular fatty acid compositions, a loop of cell mass was harvested and fatty acid methyl esters were prepared and identified according to the instructions of the Microbial Identification System (MIDI).

DNA base composition. The DNA $\mathrm{G}+\mathrm{C}$ content was determined by the method of Tamaoka \& Komagata (1984). DNA was hydrolysed and the resultant nucleotides were analysed by reversed-phase HPLC.

16S rDNA sequencing and phylogenetic analysis. 16S rDNA was amplified by PCR using two universal primers as described previously (Yoon et al., 1998). The PCR product was purified with a QIAquick PCR purification kit (Qiagen). Sequencing of the purified 16S rDNA was performed using an ABI PRISM BigDye Terminator cycle sequencing ready reaction kit (Applied Biosystems) as recommended by the manufacturer. The purified sequencing reaction mixtures were electrophoresed automatically using an Applied Biosystems model 310 automatic DNA sequencer. Alignment of sequences was carried out with CLUSTAL W software (Thompson et al., 1994). Gaps at the 5' and $3^{\prime}$ ends of the alignment were omitted from further analysis. Phylogenetic trees were inferred using three tree-making algorithms, i.e. the neighbour-joining (Saitou \& Nei, 1987), maximumlikelihood (Felsenstein, 1981) and maximum-parsimony (Kluge \& Farris, 1969) methods in the PHYLIP package (Felsenstein, 1993). Evolutionary distance matrices for the neighbour-joining method were calculated with the algorithm of Jukes \& Cantor (1969) with the DNADIST program. The stability of relationships was assessed by a bootstrap analysis based on 1000 resamplings of the neighbour-joining dataset using the programs SEQBOOT and CONSENSE of the PHYLIP package. 


\section{RESULTS}

\section{Morphology}

Most cells of strain YKJ-13 ${ }^{\mathrm{T}}$ were rods measuring $1 \cdot 0-1 \cdot 2 \times 2 \cdot 0-4.0 \mu \mathrm{m}$ in $3 \mathrm{~d}$ culture on marine agar at $30{ }^{\circ} \mathrm{C}$; however, longer rods were often observed. Cells were Gram-variable and motile by means of peritrichous flagella. Round spores were located subterminally or terminally in swollen sporangia. After incubation on marine agar, colonies were smooth, glistening, irregular, flat-raised and orange-yellow in colour.

\section{Cultural and physiological characteristics}

Strain YKJ $-13^{\mathrm{T}}$ grew optimally at $30-35^{\circ} \mathrm{C}$. Growth occurred at 10 and $45^{\circ} \mathrm{C}$, but not at 4 or $50^{\circ} \mathrm{C}$. It grew optimally at $\mathrm{pH} 7 \cdot 0-8 \cdot 0$ and no growth was

Table 1. Differential phenotypic characteristics of strain $\mathrm{YKJ}-13^{\top}$ and B. marinus

+ , Positive reaction; - , negative reaction; $\mathrm{w}+$, weakly positive reaction; $\mathrm{v}$, variable reaction. Both species were rod-shaped, produced round spores (terminal or subterminal), had peritrichous flagella and were positive for motility, catalase, decomposition of aesculin and gelatin, and acid production from glucose, fructose, maltose, sucrose and trehalose. Both species were negative for decomposition of starch and urea, and acid production from adonitol, arabinose, cellobiose, rhamnose and sorbitol.

\begin{tabular}{|c|c|c|}
\hline Characteristic & Strain YKJ-13 ${ }^{T}$ & B. marinus* \\
\hline Swollen sporangia & + & - or slightly \\
\hline Gram staining & $\mathrm{V}$ & + \\
\hline Pigment & + & - \\
\hline Anaerobic growth & + & - \\
\hline Cytochrome oxidase & + & $\mathrm{v}(-)$ \\
\hline Nitrate reduction & + & $\mathrm{v}(-)$ \\
\hline \multicolumn{3}{|l|}{ Decomposition of: } \\
\hline Casein & + & $\mathrm{v}(+)$ \\
\hline Hypoxanthine & - & $-\dagger$ \\
\hline Tween 80 & + & $-\dagger$ \\
\hline Tyrosine & - & $-\dagger$ \\
\hline Xanthine & - & $-\dagger$ \\
\hline \multicolumn{3}{|l|}{ Acid production from: } \\
\hline Lactose & - & $\mathrm{v}(+)$ \\
\hline Xylose & - & $\mathrm{v}(+)$ \\
\hline Galactose & + & - \\
\hline Mannitol & + & - \\
\hline Mannose & - & + \\
\hline Melibiose & + & - \\
\hline Raffinose & + & - \\
\hline \multicolumn{3}{|l|}{ Growth in $\mathrm{NaCl}$ at: } \\
\hline $0 \%$ & - & - \\
\hline $7 \%$ & + & $\mathrm{v}(\mathrm{W}+)$ \\
\hline $10 \%$ & + & - \\
\hline $20 \%$ & $\mathrm{w}+$ & - \\
\hline $21 \%$ & - & - \\
\hline \multicolumn{3}{|l|}{ Growth at $\left({ }^{\circ} \mathrm{C}\right)$ : } \\
\hline 5 & - & + \\
\hline 10 & + & + \\
\hline 30 & + & $\mathrm{v}(+)$ \\
\hline 37 & + & - \\
\hline Optimum growth temperature $\left({ }^{\circ} \mathrm{C}\right)$ & $30-35$ & $12-23$ \\
\hline Maximum growth temperature $\left({ }^{\circ} \mathrm{C}\right)$ & $45-50$ & $25-30$ \\
\hline Peptidoglycan type & L-Lys-direct & L-Lys-direct $\dagger$ \\
\hline Predominant menaquinone & MK-7, MK-8 & MK-7† \\
\hline Major fatty acid & iso- $\mathrm{C}_{15: 0}$ & anteiso- $\mathrm{C}_{15: 0} \dagger^{\dagger}$ \\
\hline $\mathrm{G}+\mathrm{C}$ content $(\mathrm{mol} \%)$ & 44 & $37-42$ \\
\hline
\end{tabular}

* Data from Rüger \& Richter (1979), Rüger (1983) and Rüger et al. (2000), except where indicated. Data in parentheses are for the type strain of B. marinus from Rüger \& Richter (1979), Rüger (1983) or Rüger et al. (2000).

$\dagger$ Data are for B. marinus DSM $1297^{\mathrm{T}}$ obtained from this study. 
Table 2. Cellular fatty acid profiles of strain $\mathrm{YKJ}-13^{\top}$ and $B$. marinus DSM $1297^{\top}$ on marine agar

\begin{tabular}{|c|c|c|c|c|c|c|c|c|c|c|c|c|c|c|}
\hline \multirow[t]{2}{*}{ Strain } & \multicolumn{14}{|c|}{ Fatty acid composition (\%)* } \\
\hline & $\mathrm{i}-\mathrm{C}_{14: 0}$ & $\mathrm{C}_{14: 0}$ & $\mathrm{i}-\mathrm{C}_{15: 0}$ & ai- $\mathrm{C}_{15: 0}$ & $\mathrm{C}_{15: 0}$ & $\mathbf{C}_{16: 1} \omega 7 c$ alcohol & $\mathbf{C}_{16: 1} \omega 11 c$ & $\mathrm{i}-\mathrm{C}_{16: 0}$ & $\mathrm{C}_{16: 0}$ & $\mathbf{i}-\mathbf{C}_{17: 1} \omega \mathbf{1 0} c$ & $\mathrm{i}-\mathrm{C}_{17: 0}$ & ai- $\mathrm{C}_{17: 0}$ & $\mathrm{C}_{18: 0}$ & Summed feature $5 \dagger$ \\
\hline Strain YKJ-13 ${ }^{\mathrm{T}}$ & $2 \cdot 1$ & $0 \cdot 7$ & $47 \cdot 6$ & $15 \cdot 2$ & $1 \cdot 1$ & $5 \cdot 2$ & $1 \cdot 2$ & $1 \cdot 9$ & $3 \cdot 9$ & $3 \cdot 8$ & $6 \cdot 5$ & $4 \cdot 6$ & $3 \cdot 4$ & $2 \cdot 8$ \\
\hline $\begin{array}{l}\text { B. marinus } \\
\text { DSM } 1297^{\mathrm{T}}\end{array}$ & $5 \cdot 3$ & ND & $22 \cdot 2$ & $47 \cdot 7$ & ND & $2 \cdot 6$ & ND & $5 \cdot 1$ & $1 \cdot 5$ & ND & $2 \cdot 6$ & $10 \cdot 7$ & ND & $2 \cdot 3$ \\
\hline
\end{tabular}

ND, Not detected.

* i, iso; ai, anteiso.

$\dagger$ Summed feature 5 represents iso- $\mathrm{C}_{17: 1}$ I and/or anteiso- $\mathrm{C}_{17: 1} \mathrm{~B}$, which could not be separated by GLC with the MIDI system.

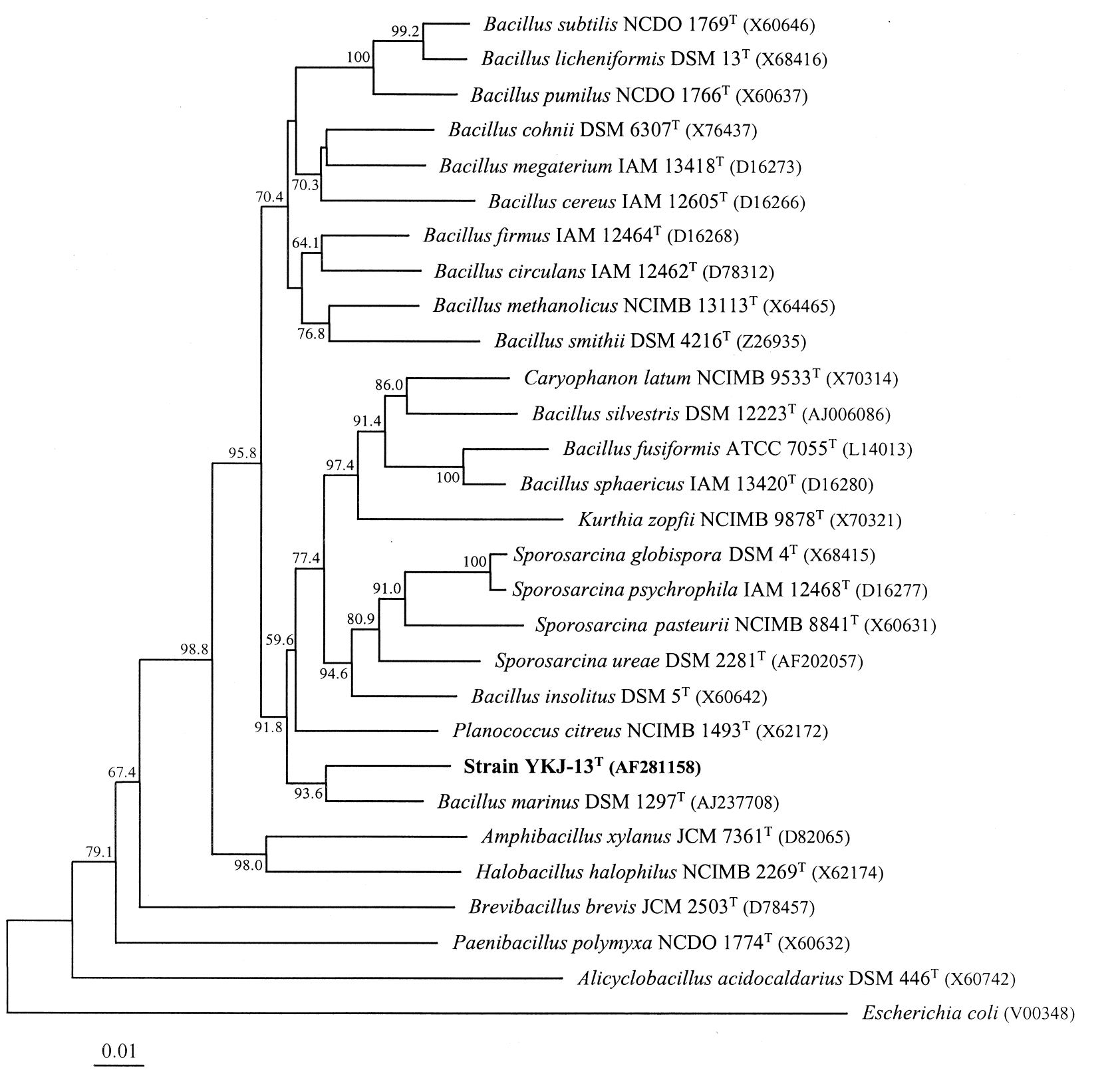

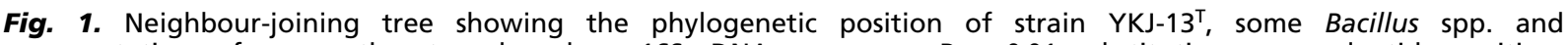
representatives of some other taxa based on 16S rDNA sequences. Bar, 0.01 substitution per nucleotide position. Bootstrap values (expressed as percentages of 1000 replications) greater than $50 \%$ are shown at the branch points. 
observed at $\mathrm{pH}$ values below $6 \cdot 0$. Strain $\mathrm{YKJ}-13^{\mathrm{T}}$ grew optimally in the presence of $3-12 \%(\mathrm{w} / \mathrm{v}) \mathrm{NaCl}$. It grew in the presence of $19 \%(\mathrm{w} / \mathrm{v}) \mathrm{NaCl}$ and weakly in the presence of $20 \% \mathrm{NaCl}$. Growth did not occur in the presence of more than $21 \%(\mathrm{w} / \mathrm{v}) \mathrm{NaCl}$. Strain YKJ-13 ${ }^{\mathrm{T}}$ grew under anaerobic conditions on marine agar. Strain $\mathrm{YKJ}-13^{\mathrm{T}}$ showed catalase and oxidase activities, but no urease activity. Aesculin, casein, gelatin and Tween 80 were hydrolysed; no hydrolysis of hypoxanthine, starch, tyrosine or xanthine was observed. Nitrate was reduced to nitrite. Phenotypic properties of strain $\mathrm{YKJ}-13^{\mathrm{T}}$ are summarized in Table 1, together with those of B. marinus.

\section{Chemotaxonomic characteristics and DNA base composition}

No diaminopimelic acid was found as the diagnostic amino acid in the cell wall hydrolysate of strain YKJ$13^{\mathrm{T}}$. The cell wall of strain $\mathrm{YKJ}-13^{\mathrm{T}}$ contained a directly cross-linked peptidoglycan with L-lysine as the diagnostic diamino acid. On the basis of this result, it was concluded that the peptidoglycan type of strain YKJ-13 $13^{\mathrm{T}}$ is $\mathrm{A} 1 \alpha$, based directly on L-Lys, as described by Schleifer \& Kandler (1972). Dinitrophenylated cell walls of strain YKJ-13 $3^{\mathrm{T}}$ contained only $\varepsilon$-DNP-lysine, thus confirming the above-mentioned type. B. marinus DSM $1297^{\mathrm{T}}$ had a directly cross-linked peptidoglycan based on L-lysine as the diamino acid. The $\alpha$-carboxyl group of D-glutamic acid was substituted by a glycine residue. This result also has recently been proven by Rüger et al. (2000). To our knowledge, this type has not been found in any other organism up to now. Strain YKJ-13 $3^{\mathrm{T}}$ contained MK-7 (62\%) as the predominant menaquinone and also a significant amount of MK-8 (35\%). B. marinus DSM $1297^{\mathrm{T}}$ contained a large proportion of MK-7 (87\%). The cellular fatty acid profile of strain $\mathrm{YKJ}-13^{\mathrm{T}}$ was characterized by the predominance of iso- $\mathrm{C}_{15: 0}(47 \cdot 6 \%)$ followed by anteiso- $\mathrm{C}_{15: 0}(15 \cdot 2 \%)$, whereas B. marinus DSM $1297^{\mathrm{T}}$ was characterized by the predominance of anteiso$\mathrm{C}_{15: 0}(47 \cdot 7 \%)$ and the occurrence of significant amounts of iso- $\mathrm{C}_{15: 0}(22 \cdot 2 \%)$ and anteiso- $\mathrm{C}_{17: 0}$ $(10.7 \%)$ (Table 2). The DNA G $+\mathrm{C}$ content of strain YKJ-13 ${ }^{\mathrm{T}}$ was $44 \mathrm{~mol} \%$.

\section{Phylogenetic analysis}

The 16S rDNA of strain YKJ-13 ${ }^{\mathrm{T}}$ was directly sequenced after PCR amplification and its almost complete nucleotide sequence was determined. This sequence comprised $1508 \mathrm{nt}$, representing approximately $96 \%$ of the Escherichia coli 16S rRNA sequence. In the treebased neighbour-joining algorithm, strain $\mathrm{YKJ}-13^{\mathrm{T}}$ was phylogenetically related to members of Bacillus rRNA group 2 and formed a coherent cluster with B. marinus DSM $1297^{\mathrm{T}}$ (Fig. 1). The clustering fidelity between strain YKJ-13 ${ }^{\mathrm{T}}$ and B. marinus DSM $1297^{\mathrm{T}}$ was supported by bootstrap analysis at a confidence level of $93.6 \%$. The relationship between this cluster and the cluster comprising members of Bacillus rRNA group 2 was supported by a relatively high bootstrap resampling value of $91.8 \%$. The phylogenetic relationship between strain $\mathrm{YKJ}-13^{\mathrm{T}}, B$. marinus and members of Bacillus rRNA group 2 was also found in trees generated by the maximum-likelihood and maximum-parsimony algorithms. Strain YKJ-13 ${ }^{\mathrm{T}}$ showed the highest degree of relatedness to B. marinus DSM $1297^{\mathrm{T}}$, sharing $95.7 \%$ 16S rDNA similarity. Sequence similarity values of $16 \mathrm{~S}$ rDNA from strain YKJ-13 ${ }^{\mathrm{T}}$ with $16 \mathrm{~S}$ rDNA from the type strains of Bacillus species belonging to rRNA group 2 were in the range $92 \cdot 4-93.9 \%$. Strain YKJ-13 $3^{\mathrm{T}}$ exhibited levels of $16 \mathrm{~S}$ rDNA similarity of less than $94.2 \%$ with the type strains of other Bacillus species that had known $16 \mathrm{~S}$ rDNA sequences.

\section{DISCUSSION}

Many bacilli have been recently isolated from jeotgal. In the course of characterizing these strains, one isolate (strain YKJ-13 ${ }^{\mathrm{T}}$ ) has attracted our attention because of its morphological characteristic of forming round endospores and its moderately halophilic physiology. 16S rDNA sequence analysis showed that strain YKJ$13^{\mathrm{T}}$ was phylogenetically related to the radiation of a cluster comprising members of Bacillus rRNA group 2 , with the formation of a coherent cluster with $B$. marinus (Fig. 1). Strain YKJ-13 ${ }^{\mathrm{T}}$ contained L-lysine at position 3 of the cell wall peptidoglycan, which is characteristic of Bacillus rRNA group 2 (Rheims et al., 1999; Stackebrandt et al., 1987). Strain YKJ-13 ${ }^{\mathrm{T}}$ had MK-7 and MK-8 as the predominant menaquinones and iso- $\mathrm{C}_{15: 0}$ as the major fatty acid. Among the rRNA group 2 bacilli, some species, such as Bacillus sphaericus and Bacillus silvestris, have been found to contain iso- $\mathrm{C}_{15: 0}$ as the major fatty acid (Rheims et al., 1999; Shida et al., 1997). On the basis of these data, strain $\mathrm{YKJ}-13^{\mathrm{T}}$ is considered to be a member of Bacillus rRNA group 2. Results showed that the type strain of B. marinus had MK-7 as the predominant menaquinone and L-lysine at position 3 of the peptide subunit of the peptidoglycan. B. marinus has already been known to form round endospores (Rüger, 1983; Claus \& Berkeley, 1986). Accordingly, B. marinus must also be a member of Bacillus rRNA group 2 .

16S rDNA sequence comparison showed that strain YKJ $-13^{\mathrm{T}}$ and the type strain of $B$. marinus exhibited the closest phylogenetic relationship, with $95.7 \%$ similarity. There were some physiological differences between strain $\mathrm{YKJ}-13^{\mathrm{T}}$ and $B$. marinus, such as the ability to grow anaerobically, and $\mathrm{NaCl}$ and growth temperature tolerances (Table 1). Whereas B. marinus showed slight growth at $7 \% \mathrm{NaCl}$ and no growth at $10 \% \mathrm{NaCl}$, strain YKJ-13 ${ }^{\mathrm{T}}$ grew at $20 \% \mathrm{NaCl}$ (Table 1). Strain $\mathrm{YKJ}-13^{\mathrm{T}}$ is a mesophile growing at 10 and $45^{\circ} \mathrm{C}$ with an optimum of $30-35^{\circ} \mathrm{C}$, whereas $B$. marinus is a psychrophile showing a growth range of $5-30{ }^{\circ} \mathrm{C}$, with an optimum of $12-23^{\circ} \mathrm{C}$ (Table 1 ). Some chemotaxonomic properties are important for distinguishing strain $\mathrm{YKJ}-13^{\mathrm{T}}$ from $B$. marinus. It is noteworthy that the fatty acid profile of strain YKJ$13^{\mathrm{T}}$ differed from that of B. marinus DSM $1297^{\mathrm{T}}$. 
Strain YKJ-13 ${ }^{\mathrm{T}}$ and B. marinus DSM $1297^{\mathrm{T}}$ showed a distinct difference in the amounts of iso- $\mathrm{C}_{15: 0}$ and anteiso- $\mathrm{C}_{15: 0}$ they contained (Table 2). Strain YKJ$13^{\mathrm{T}}$ could be distinguished from the type strain of $B$. marinus by menaquinone composition. The menaquinone profile of strain $\mathrm{YKJ}-13^{\mathrm{T}}$ was characterized by the predominance of MK-7 (62\%) followed by MK-8 $(35 \%)$, whereas B. marinus DSM $1297^{\mathrm{T}}$ has $87 \%$ MK-7 and no MK-8. This menaquinone profile of strain YKJ-13 ${ }^{\mathrm{T}}$ has not been found in other bacilli belonging to rRNA group 2 (Rheims et al., 1999). $B$. marinus DSM $1297^{\mathrm{T}}$ has a unique peptidoglycan structure that has not been found in any other organism. On the basis of these data, particularly chemotaxonomic data, strain $\mathrm{YKJ}-13^{\mathrm{T}}$ and B. marinus should be distinguished as members of different genera in Bacillus rRNA group 2.

The taxonomic status of the rRNA group 2 bacilli has recently been discussed. It has been recognized that Bacillus species belonging to this group should be taxonomically distinguished from Bacillus rRNA group 1, including Bacillus subtilis, the type species of this genus, and all meso-diaminopimelic acid-containing bacilli by micromorphology, phylogeny and cell wall composition (Farrow et al., 1994). Therefore, the L-lysine- and D-ornithine-containing bacilli of rRNA group 2 may be in need of taxonomic re-evaluation to transfer them into several new genera or existing genera. Since no proposal about taxonomic reclassification of the rRNA group 2 bacilli has been forwarded, Rheims et al. (1999) proposed that any strain worthy of species rank within rRNA group 2, exhibiting taxonomic properties that would identify this taxon as a member of the genus Bacillus, should still be described as a species of this genus. However, there is no longer any reason to delay taxonomic re-evaluation of the rRNA group 2 bacilli. Recently, B. globisporus, Bacillus psychrophilus and Bacillus pasteurii, which belong to rRNA group 2, together with one novel isolate, were transferred to the genus Sporosarcina (Yoon et al., 2001). Accordingly, it appears to be more appropriate that strain YKJ-13 ${ }^{\mathrm{T}}$ and B. marinus be placed within two other genera, not the genus Bacillus.

Therefore, the creation of a new genus and species, Jeotgalibacillus alimentarius gen. nov., sp. nov., for strain YKJ-13 ${ }^{\mathrm{T}}$ and the reclassification of $B$. marinus (Rüger 1983) in a new genus, Marinibacillus gen. nov., as Marinibacillus marinus comb. nov. are proposed.

\section{Description of Jeotgalibacillus gen. nov.}

Jeotgalibacillus (Je.ot.ga.li.ba.cil'lus. Korean n. jeotgal jeotgal, traditional Korean food; Gr. n. baktron rod; N.L. masc. n. Jeotgalibacillus rod from jeotgal).

Rod-shaped bacterium. Round endospores are observed in swollen sporangia. Catalase- and oxidasepositive. Urease-negative. Nitrate is reduced to nitrite. Cell wall peptidoglycan contains L-lysine at position 3 of the peptide subunit. Predominant menaquinones are MK-7 and MK-8. Major fatty acid is iso- $\mathrm{C}_{15: 0}$. DNA $\mathrm{G}+\mathrm{C}$ content is $44 \mathrm{~mol} \%$ (determined by HPLC). Type species is Jeotgalibacillus alimentarius.

\section{Description of Jeotgalibacillus alimentarius sp. nov.}

Jeotgalibacillus alimentarius (a.li.men.ta'ri.us. L. adj. alimentarius relating to food).

Gram-variable, facultatively anaerobic rods of $1 \cdot 0$ $1 \cdot 2 \times 2.0-4.0 \mu \mathrm{m}$; longer rods are often observed. Round endospores lie subterminally or terminally in swollen sporangia. Motile by means of peritrichous flagella. Colonies are smooth, glistening, irregular, flat to raised and orange-yellow in colour on marine agar. Grows in the presence of $19 \% \mathrm{NaCl}$ and weakly in the presence of $20 \% \mathrm{NaCl}$. Growth occurs at 10 and $45^{\circ} \mathrm{C}$, but not at 4 or $50^{\circ} \mathrm{C}$. Optimal growth temperature is $30-35^{\circ} \mathrm{C}$. Optimal $\mathrm{pH}$ for growth is $\mathrm{pH}$ $7 \cdot 0-8.0$ and no growth is observed at $\mathrm{pH} 6.0$. Catalaseand oxidase-positive. Urease-negative. Aesculin, casein, gelatin and Tween 80 are hydrolysed; no hydrolysis of hypoxanthine, starch, tyrosine or xanthine is observed. Nitrate is reduced to nitrite. Acid is produced from D-ribose, D-fructose, D-mannitol, melibiose, D-melezitose, D-glucose, D-galactose, sucrose, maltose, D-trehalose and D-raffinose. Acid is not produced from D-sorbitol, myo-inositol, D-xylose, Larabinose, D-mannose, adonitol, L-rhamnose, Dcellobiose, stachyose or lactose. Peptidoglycan type is A $1 \alpha$ (L-Lys-direct). Predominant menaquinones are MK-7 and MK-8. Major fatty acid is iso- $\mathrm{C}_{15: 0}$. DNA $\mathrm{G}+\mathrm{C}$ content is $44 \mathrm{~mol} \%$ (determined by HPLC). Isolated from jeotgal, traditional Korean fermented seafood. Type strain is strain $\mathrm{YKJ}-13^{\mathrm{T}}(=\mathrm{KCCM}$ $80002^{\mathrm{T}}=\mathrm{JCM} 10872^{\mathrm{T}}$ ).

\section{Description of Marinibacillus gen. nov.}

Marinibacillus (Ma.ri.ni.ba.cil'lus. L. adj. marinus of the sea; Gr. n. baktron rod; M.L. masc. n. Marinibacillus rod of the sea).

The description is the same as that given by Rüger (1983) and Rüger et al. (2000). Additional chemotaxonomic characters found in this study are as follows: cell wall peptidoglycan contains L-lysine at position 3 of the peptide subunit; the predominant menaquinone is MK-7; and the major fatty acid is anteiso- $_{15: 0}$. Type species is Marinibacillus marinus.

\section{Description of Marinibacillus marinus comb. nov. (basonym Bacillus marinus Rüger 1983)}

The species description is as given above for the genus. Type strain is DSM $1297^{\mathrm{T}}$.

\section{ACKNOWLEDGEMENTS}

This work was supported by grants HS2701 and HSS0310033 from the Ministry of Science and Technology (MOST) of the Republic of Korea and by the research fund of the Probionic Corporation of Korea. 


\section{REFERENCES}

Ash, C., Farrow, J. A. E., Wallbanks, S. \& Collins, M. D. (1991). Phylogenetic heterogeneity of the genus Bacillus as revealed by comparative analysis of small-subunit-ribosomal RNA sequences. Lett Appl Microbiol 13, 202-206.

Claus, D. \& Berkeley, R. C. W. (1986). Genus Bacillus Cohn 1872. In Bergey's Manual of Systematic Bacteriology, vol. 2, pp. 1105-1140. Edited by P. H. A. Sneath, N. S. Mair, M. E. Sharpe \& J. G. Holt. Baltimore: Williams \& Wilkins.

Clausen, V., Jones, J. G. \& Stackebrandt, E. (1985). 16S ribosomal RNA analysis of Filibacter limicola indicates a close relationship to the genus Bacillus. J Gen Microbiol 131, 2659-2663.

Cowan, S. T. \& Steel, K. J. (1965). Manual for the Identification of Medical Bacteria. London: Cambridge University Press.

Farrow, J. A. E., Ash, C., Wallbanks, S. \& Collins, M. D. (1992). Phylogenetic analysis of the genera Planococcus, Marinococcus and Sporosarcina and their relationships to members of the genus Bacillus. FEMS Microbiol Lett 93, 167-172.

Farrow, J. A. E., Wallbanks, S. \& Collins, M. D. (1994). Phylogenetic interrelationships of round-spore-forming bacilli containing cell walls based on lysine and the non-sporeforming genera Caryophanon, Exiguobacterium, Kurthia, and Planococcus. Int J Syst Bacteriol 44, 74-82.

Felsenstein, J. (1981). Evolutionary trees from DNA sequences: a maximum likelihood approach. $J$ Mol Evol 17, 368-376.

Felsenstein, J. (1993). PHYLIP (phylogenetic inference package), version 3.5. Department of Genetics: University of Washington, Seattle, USA.

Jukes, T. H. \& Cantor, C. R. (1969). Evolution of protein molecules. In Mammalian Protein Metabolism, vol. 3, pp. 21-132. Edited by H. N. Munro. New York: Academic Press.

Kluge, A. G. \& Farris, F. S. (1969). Quantitative phyletics and the evolution of anurans. Syst Zool 18, 1-32.

Komagata, K. \& Suzuki, K. (1987). Lipids and cell-wall analysis in bacterial systematics. Methods Microbiol 19, 161-203.

Lanyi, B. (1987). Classical and rapid identification methods for medically important bacteria. Methods Microbiol 19, 1-67.

Leifson, E. (1963). Determination of carbohydrate metabolism of marine bacteria. J Bacteriol 85, 1183-1184.

Rheims, H., Frühling, A., Schumann, P., Rohde, M. \& Stackebrandt, E. (1999). Bacillus silvestris sp. nov., a new member of the genus Bacillus that contains lysine in its cell wall. Int J Syst Bacteriol 49, 795-802.

Rüger, H.-J. (1983). Differentiation of Bacillus globisporus, Bacillus marinus comb. nov., Bacillus aminovorans, and Bacillus insolitus. Int J Syst Bacteriol 33, 157-161.
Rüger, H.-J. \& Richter, G. (1979). Bacillus globisporus subsp. marinus subsp. nov. Int J Syst Bacteriol 29, 196-203.

Rüger, H.-J, Fritze, D. \& Spröer, C. (2000). New psychrophilic and psychrotolerant Bacillus marinus strains from tropical and polar deep-sea sediments and emended description of the species. Int J Syst Evol Microbiol 50, 1305-1313.

Saitou, N. \& Nei, M. (1987). The neighbor-joining method: a new method for reconstructing phylogenetic trees. Mol Biol Evol 4, 406-425.

Schleifer, K. H. \& Kandler, O. (1972). Peptidoglycan types of bacterial cell walls and their taxonomic implications. Bacteriol Rev 36, 407-477.

Shida, O., Takagi, H., Kadowaki, K., Nakamura, L. K. \& Komagata, K. (1997). Transfer of Bacillus alginolyticus, Bacillus chondroitinus, Bacillus curdlanolyticus, Bacillus glucanolyticus, Bacillus kobensis, and Bacillus thiaminolyticus to the genus Paenibacillus and emended description of the genus Paenibacillus. Int J Syst Bacteriol 47, 289-298.

Stackebrandt, E., Ludwig, W., Weizenegger, M., Dorn, S., McGill, T. J., Fox, G. E., Woese, C. R., Schubert, W. \& Schleifer, K.-H. (1987). Comparative 16S rRNA oligonucleotide analyses and murein types of round-spore-forming bacilli and non-sporeforming relatives. J Gen Microbiol 133, 2523-2529.

Tamaoka, J. \& Komagata, K. (1984). Determination of DNA base composition by reverse-phase high-performance liquid chromatography. FEMS Microbiol Lett 25, 125-128.

Thompson, J. D., Higgins, D. G. \& Gibson, T. J. (1994). CLUSTAL $\mathrm{W}$ : improving the sensitivity of progressive multiple sequence alignment through sequence weighting, position-specific gap penalties and weight matrix choice. Nucleic Acids Res 22, 4673-4680.

Yoon, J.-H., Kim, H., Kim, S.-B., Kim, H.-J., Kim, W. Y., Lee, S. T., Goodfellow, M. \& Park, Y.-H. (1996). Identification of Saccharomonospora strains by the use of genomic DNA fragments and rRNA gene probes. Int $J$ Syst Bacteriol 46, 502-505.

Yoon, J.-H., Lee, S. T. \& Park, Y.-H. (1998). Inter- and intraspecific phylogenetic analysis of the genus Nocardioides and related taxa based on 16S rDNA sequences. Int J Syst Bacteriol 48, 187-194.

Yoon, J.-H., Lee, K.-C., Weiss, N., Kho, Y. H., Kang, K. H. \& Park, Y.-H. (2001). Sporosarcina aquimarina sp. nov., a bacterium isolated from a seawater in Korea, and transfer of Bacillus globisporus (Larkin \& Stokes 1967), Bacillus psychrophilus (Nakamura 1984) and Bacillus pasteurii (Chester 1898) to the genus Sporosarcina as Sporosarcina globispora comb. nov., Sporosarcina psychrophila comb. nov. and Sporosarcina pasteurii comb. nov., and emended description of the genus Sporosarcina. Int J Syst Evol Microbiol 51, 1079-1086. 